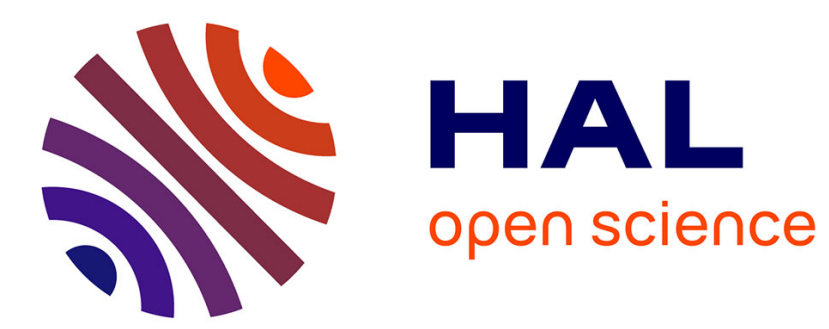

\title{
The Social Brain: a Spinozist Reconstruction
}

\author{
Charles T. Wolfe
}

\section{To cite this version:}

Charles T. Wolfe. The Social Brain: a Spinozist Reconstruction. ASCS 2009, John Sutton et al, Sep 2009, Sydney, Australia. 10.5096/ASCS200956 . hal-01233165

\section{HAL Id: hal-01233165 \\ https://hal.science/hal-01233165}

Submitted on 4 Dec 2015

HAL is a multi-disciplinary open access archive for the deposit and dissemination of scientific research documents, whether they are published or not. The documents may come from teaching and research institutions in France or abroad, or from public or private research centers.
L'archive ouverte pluridisciplinaire HAL, est destinée au dépôt et à la diffusion de documents scientifiques de niveau recherche, publiés ou non, émanant des établissements d'enseignement et de recherche français ou étrangers, des laboratoires publics ou privés. 


\title{
The Social Brain: a Spinozist Reconstruction
}

\author{
Charles T. Wolfe (c.wolfe@,usyd.edu.au) \\ Unit for History and Philosophy of Science \\ University of Sydney \\ Carslaw F07, Sydney NSW 2006
}

\begin{abstract}
The sciences of cognition, going back to the early days of the Artificial Intelligence movement in the 1950 s, were typically viewed with profound suspicion or distaste by thinkers, Marxist and other, for whom the embeddedness of human beings in the symbolic realm of representations and values was a sine qua non condition of any legitimate theory whether ethical, political, metaphysical. Attempts to locate mind and action within the natural world studied by the natural sciences, in this case by neuroscience, were viewed as at best conceptual justifications for de-humanizing, secret military projects. The fact that in recent years the sciences of cognition have had a 'social turn' ("social cognition," "social neuroscience," "affective neuroscience," “collective intentionality" and so forth) does little to assuage the fears of the engagé, anti-naturalist thinker. In contrast, I propose a historic-philosophical reconstruction of a 'Spinozist' tradition which locates the brain within the broader network of relations, including social relations. This tradition runs from Spinoza to Marx and Lev Vygotski in the early $20^{\text {th }}$ century, and on to Toni Negri and Paolo Virno in recent European philosophy, as a new perspective on the brain. The concept of social brain that is articulated in this reconstruction - some early- $20^{\text {th }}$ century Soviet neuropsychologists spoke of the "socialist cortex" - overcomes distinctions between Continental thought and the philosophy of mind (and its ancillary, cognitive science), and possibly gives a new metaphysical framework for social cognition.
\end{abstract}

Keywords: social brain; Spinoza; Vygotski

There have been lots of discussions of social intellect and even social cognition in recent decades, which brought about a significant change in what might have otherwise been a very 'individualist' discipline, with a new focus on imitation, empathy, 'mind-reading', and even group cognition. And claims that the mind or intellect is by essence social go back a long ways - consider Locke's statement that "I have always thought the Actions of Men the best Interpreters of their thoughts,"1 a position which reaches its mature expression in the pragmatist understanding of mind as a set of practices within the world of action, but also in the different forms of behaviorism (psychological and logical); in the philosophy of the later Wittgenstein, or in Heidegger-as-read-by-Hubert-Dreyfus, and 'ecological' thinking à la J.J. Gibson. ${ }^{2}$

But I will be interested in a different locus of the social here: the brain. And differently from the newly emerged

\footnotetext{
${ }^{1}$ Locke (1975), I.iii.3.

${ }^{2}$ See Losonsky (2001), pp. 8-9; Clark (1997), (2002).
}

field of social neuroscience, the social brain I shall discuss here might also be called 'The Spinozist Brain' or, in a more mysterious formulation, from a 1920s Bolshevik psychologist, Aaron Zalkind, 'The Socialist Cortex'. I shall clarify this expression later on, but for now would emphasize the Spinozist dimension. That is, I wish to reconstruct a tradition of thinking about the brain as social which is ultimately Spinozist in nature, via Marx, Lev Vygotski and the contemporary philosopher Antonio Negri. One of the points I will make in light of this reconstruction is that the Marxist hostility to cognitive science might have to be reconsidered to some extent. (Marx himself uses the expression 'social brain'. ${ }^{3}$ ) Or, put differently, that an incidental accomplishment of the presentation of this tradition should be to make it harder for politically motivated critiques of cognitive science and artificial intelligence to make it seem as if theories of intellect and action that sought to involve the brain necessarily had to be individualistic, 'reactionary', in the service of the militaryindustrial complex, and so forth. ${ }^{4}$

Obviously not all 'social brains' or rather their conceptualizations, are equal. Social epistemology, primacy of emotions and the importance of 'common notions' are not all the same. The 'social' dimension being emphasized in the discussions of 'social intellect', ${ }^{5}$ which culminated in the notion of 'Machiavellian intelligence' and its presence in the primate world, is that of the individual's capacity to interact successfully with social groups, to predict and manipulate behavior, to make and break promises, and so forth. The energetic demands of such a complex situation are ultimately presented as responsible for the large size of primates' brains, so that some evolutionary anthropologists and their collaborators in related fields took to calling the Machiavellian Intelligence hypothesis, the 'social brain hypothesis'. ${ }^{6}$

The 'social' in 'social epistemology' focuses on the reliability of collective states of mind, whereas the social in 'social cognition' focuses notably on mirror neurons, which

\footnotetext{
${ }^{3}$ Marx (1973), pp. 694, 709.

${ }^{4}$ The most eloquent version of this slightly paranoid critique (and the Rand Corporation, DARPA and others will keep such theorists busy for generations to come) is the long, anonymous text entitled "L'hypothèse cybernétique," in the post-Situationist journal Tiqqun 2 (2001), p. 40f.

${ }^{5}$ Humphrey, "The social function of intellect" (1976), reprinted in Byrne \& Whiten, eds. (1988); see also the sequel, Whiten \& Byrne, eds. (1997).

${ }^{6}$ Brothers (1990); Dunbar (1998), Dunbar et al. (Eds.) (2009).
} 
indicate the existence in the brain of a particular recognition or decoding of action and thus of the imitation of action, ${ }^{7}$ indicating an understanding of other people's intentions, goals and desires. Mirror neurons, found in the ventral premotor cortex of macaque monkeys, are activated both when the monkey executes grasping actions (e.g. grasping a peanut) and when it observes someone else (or another monkey) making grasping actions, or even the preparation of a motor act. Mirror neurons appear to distinguish between biological and nonbiological actions, responding only to the observation of hand-object interactions and not to the same action if performed by a mechanical tool, such as a pair of pliers. ${ }^{8}$

Imitation had already been pinpointed in the late nineteenth century by Baldwin (of 'Baldwin effect' fame): "By imitation the little animal picks up directly the example, instruction, mode of life, etc. of his private family circle and species." ${ }^{\prime}$ And in the 1920s the great reformer John Dewey extensively elaborated an account of the social basis of mind. Since the early Nineties Cacioppo and Berntson have used the term 'social neuroscience' to describe their work, but this has rather little to do with our interest in the social brain, as the focus seems to be chiefly on correlations between neural states and behavior. ${ }^{10}$ Similarly with studies of the culturally and socially constructed nature of the brain, or the focus on its necessarily 'networked' dimension ('mind-like properties of social groups', as Hutchins says).; they do not make ontological claims about the brain itself.

Under the influence of J.J. Gibson, an influential paper by Andy Clark and David Chalmers, and in a different vein the 'enactivist' approach to cognition proposed by Varela and others, 'ethological' and 'ecological' approach to the study of brain, body and mind have become mainstream; they are simply part of the framework for understanding the behavior of an organism. But the environment that's studied there still tends to be viewed in terms of stimulus and response (the red spot of paint that the little bird pecks at, and so forth), and not in terms of the symbolic world, the historically, socially and culturally determined world of representations, of role-playing, of recognition in which we actually live and act. But rather than seek to broker agreement between various schools of thought, or retreat

\footnotetext{
7 Gallese, Keysers \& Rizzolatti (2004), Goldman (2005). Goldman has even co-authored papers with Gallese, on how mirror neurons help put the new concept of 'mind-reading' on solid footing. See Gallese \& Goldman (1998). A major anthology on imitation is Hurley and Chater (Eds.) (2005), which includes discussion of Alex, Irene Pepperberg's much-regretted African grey parrot.

${ }^{8}$ Blakemore, Winston \& Frith (2004), p. 217; Gallese, Keysers \& Rizzolatti (2004), p. 397.

9 Baldwin (1896), p. 440; Depew, "Baldwin and his many effects," in Depew \& Weber, eds. (2003), p. 7. I won't be able to discuss Baldwin in this paper but his views concerning language as a supplemental level beyond Darwinian evolution offer intriguing resonances with Vygotski and Negri.

${ }^{10}$ See e.g. Cacioppo \& Berntson (2004a, 2004b).

${ }^{11}$ E.g., Alač (2008) and Hutchins (1995).
}

behind the safe posture of the intellectual historian relating the discovery of the 'fact' that our selves or minds, which turn out to be our brains, are socially produced and perhaps determined, I would, as indicated above, like to analyze a tradition out of which a unique concept, 'the social brain', has emerged, from the post-Cartesian metaphysics of Spinoza to its neurological and Marxist reprisals in Vygotski and Negri.

This will not however be a study in the history of Marxism - suffice it to say that the concept of social brain appears in various passages in the works of the 'autonomist' Italian Marxist thinkers Toni Negri and Paolo Virno, where they use it synonymously with the even more mysterious expression "General Intellect," derived from the so-called 'Fragment on Machines' in Marx's Grundrisse, his notebooks of the late 1850s which Negri 'rediscovered' as a source for another, heterodox Marxism in celebrated lectures given at the École Normale Supérieure in Paris in the late 1970s, at the invitation of Louis Althusser. ${ }^{12}$ The Spinozist tradition of the social brain runs concurrently from Spinoza to Marx and his reinterpretation by Negri, and from Spinoza to the neuropsychologists Lev Semenovich Vygotski and Alexander Romanovich Luria in Russia in the 1920s-1930s. ${ }^{13}$

The story could be extended to include both the 'coevolution' approach to brain and language proposed by Terrence Deacon and, in a more 'American' and 'therapeutic' vein, the type of 'affective neuroscience' proposed by Antonio Damasio. Indeed, claims about the embodied, embedded nature of cognition, or the ultimate 'commonness' of its contents, are inseparable from an affective component, already in Spinoza (and Vygotski noticed this, authoring a manuscript on Spinoza's theory of the emotions or 'affects' which was published posthumously ${ }^{14}$ ).

I will proceed in three steps: first I'll try to make explicit the Spinozist context for the social brain, secondly I shall summarize some key ideas of the 'Russian school' (Vygotski, Luria), and lastly point towards the 'Italian' moment of Negri and others.

\section{The Spinozist context}

In an important proposition of the Ethics, Spinoza declares that "The order and the connexion of ideas is the same as the order and the connexion of things." ${ }^{15}$ Spinoza locates the individual within a world of relations; to be an individual is in fact nothing other than being a particular intersection in a

\footnotetext{
${ }^{12}$ Negri (1984). For further background on Autonomia see the prefaces by Yann Moulier and Matteo Mandarini to Negri (1989) and (2005), and Lotringer and Marazzi (Eds.) (1980/2007).

${ }^{13}$ The only work I am aware of which makes a connection between the autonomist Marxist theory of the 'social brain' and Vygotski's landmark work at the intersection of social psychology, developmental psychology, linguistics and neuroscience is Virno (2001b), himself an actor in the former movement.

${ }_{15}^{14}$ Vygotski (1972).

${ }^{15}$ Spinoza (1676/1992), II, prop. 7
} 
giant universe of relations. This is what it is to be a finite mode of an infinite substance. One might think of a connectionist model, a neural net in which particular links are reinforced. Spinoza adds that any such intersection, whether it is a stone, a Fanta can, an animal or me, strives to persevere in existence, as the finite mode it is. ${ }^{16}$ (This striving - the conatus - is frequently misread outside of Spinoza scholarship as being specifically 'vital' or 'biological', including in Damasio's version where it becomes a particular disposition of cerebral circuits such that an internal or external stimulus will induce them to seek out their well-being or survival.) The generalized character of the striving to remain one's finite mode was nicely put by the eighteenth-century French materialist d'Holbach:

All beings known to us tend to preserve themselves in the same way. The stone resists destruction by the strong adhesion of its parts. Organized beings preserve themselves in more complicated ways. . . Physicists have named this tendency or striving, self-gravitation. Newton calls it inertia, and moralists discussing human beings call it self-love. ${ }^{17}$

What this implies for Spinoza's view of the 'subject' or 'agent' is that she will not be defined by her interiority, by private mental states, a fortiori private and foundational mental states. An individual is a certain quantum of striving, and thereby a certain relation between different points in the total causal network. Exactly as a contemporary practitioner of 'social' or 'affective' neuroscience might have it, the passions are not properties of an essential human nature, or an isolated individual, but rather of a relational spectrum between a plurality of individuals. ${ }^{18}$ Instead of Descartes' cogito ergo sum Spinoza says homo cogitat (Ethics II, axiom 2): there is no foundational self, but always a process - a network.

Alexander Luria's "monistic" critique of psychology is explicitly Spinozist. ${ }^{19}$ He thinks that both Feuerbachian materialism and psychoanalysis contribute to this monistic approach, unlike the 'soul'-oriented tradition of philosophical psychology. ${ }^{20}$ In his view, psychology was too dualistic - either too mechanistic, with no recognition of activity, or too vitalistic, with no recognition of the causal (and thus deterministic) relations within which life, including mental life, takes place - and it has been this way at least since Descartes' Passions of the Soul. Similarly, Vygotski proposed a Spinozist 'reform' of psychology, arguing that

\footnotetext{
${ }^{16}$ Spinoza, (1676/1992), III, prop. VI.

${ }^{17}$ D'Holbach (1781/1990), I, pp. 82-83 (my translation).

${ }^{18}$ For a nice summary, see Morfino (2003), § 5 and Morfino (2006).

19 Luria, "Psychoanalysis as Monistic Psychology" (1925), in Luria (1978).

${ }^{20}$ Vygotski disagreed with this essay for inappropriately trying to synthesize Freudianism and Marxism without acknowledging their specific differences.
}

thinking is nothing other than a function of the brain Mental life does not have an independent existence; following Spinoza's definition, thinking is not a substance but an attribute. A 'psychic' [or 'mental' $\mathrm{CW}$ ] phenomenon does not exist in itself but is rather (...) a necessary moment in a complex psychophysical process. ${ }^{21}$

The first Spinozist point was an ontological one, about the nature of the world as a total set of interconnections within which we find ourselves as embodied agents. The second Spinozist point is the non-independence of mind and brain with regard to this world. What is missing so far is the 'selfsculpting' element, which falls under the heading of emotions or affects. Vygotski adds in another text that

Spinoza $[\ldots]$ was a determinist and, in contrast to the Stoics, claimed that man has power over his affects, that the intellect may change the order and connection of the passions and bring them into accord with the order and connections that are given in the intellect. Spinoza expressed a correct genetic relationship. In the process of ontogenetic development the human emotions get connected with general sets both in what regards the individual's self-consciousness and in what regards his knowledge of reality. ${ }^{22}$

This third point, acknowledging the 'primacy' of the affects, occurs in independent fashion in Vygotski, in Negri and in Damasio, each time with reference to Spinoza. For instance, it's precisely inasmuch as we belong to a greater causal world that we are capable of effecting changes in ourselves and internalizing knowledge from the outside (this is also Spinoza's doctrine of liberation as emendation).

Now, given these three points, if we add a fourth and last one, it will take us to the 'social brain': it is the "common notions" we have which make our persons - and, Negri will add quite consistently, our brains - common. Common notions are conceptions of things "which are common to all" (Ethics II, prop. 38). There are common notions shared between bodies, and the more I 'have' or 'know' them, the more I have adequate knowledge of body, and more materialistically, the more my body has in common with other bodies, the more my mind is capable of perceiving things adequately (ibid., prop. 39). The common notions allow us to step beyond the consideration of singular things and see (some of) the greater network-machine beyond us: we then see how finite modes are produced by an infinite substance. Put differently, with reference to the affects: they are necessarily social, being about 'otherness' or 'exteriority'. For example, laughter and sobbing are distinctly human features activated by limbic structures; importantly, they are the first two social valorizations that children make, and they induce responses in others that are

\footnotetext{
${ }^{21}$ Vygotski, "The genesis of higher mental functions," quoted in Métraux (1992), p. 197 (my translation from the German).

${ }^{22}$ Vygotski, "On Psychological Systems," in Vygotski (1997), p. 103.
} 
highly predictive of emotional states. ${ }^{23}$ Let's move now from the Spinozist context to what one Bolshevik child psychologist in the 1930s called the socialist cortex.

\section{The socialist cortex}

Given this Spinozist framework, the first real 'pass' towards the vision of the brain itself as social - of cerebral architecture as reflecting changes in the linguistic, social and cultural environments - was made by Lev Vygotski and his collaborator Alexander Luria in Russia in the 20s-30s. Vygotski died quite young but he managed to lay the foundations for a variety of fields of inquiry (he and Luria are founders of neuropsychology, along with Kurt Goldstein ${ }^{24}$ and he is a first-rank figure in social psychology, linguistics and developmental psychology). Among the unpublished manuscripts he left behind, one was on Spinoza's Doctrine of the Emotions, in light of but also as the basis for a 'psychoneurology'. The context in which the ideas that concern us appear is the development of language in the child. It has powerful resonances with 'Baldwinian evolution', an understanding of evolution which allows for behavioral adaptation to precede and condition major biological changes, so that when "useful behavior spreads within a population and becomes important for subsistence, it will generate selection pressures on generic traits that support its propagation, ${ }^{25}$ or again, "that successful learners will do better in evolutionary competition even though what is learned is not inherited."26

Vygotski describes linguistic activity as necessarily intersubjective: learning a concept involves invoking it, linking it with the performance procedure and external information for which it stands. He calls this the "outsideinside" principle, namely, that symbolic thought first represents external action, and only later becomes internal speech (i.e., thought). ${ }^{27} \mathrm{He}$ argues that concepts and functions exist for the child first in the social or interpersonal sphere and only later are internalized as intrapsychic concepts. Contra Piaget in particular, ${ }^{28}$ Vygotski argues that we don't move from a solitary, 'autistic' or 'egocentric' starting-point towards a gradual socialization, but rather from socialization towards individuality. In these different visions of child development, Piaget looks for universal laws of development, whereas Vygotski always stresses the plurality of social environments as an irreducible factor in development. But the lessons to be learned go beyond child psychology:

\footnotetext{
${ }^{23}$ Deacon (1997), p. 419.

${ }^{24}$ Van der Veer (1997), p. 5.

${ }^{25}$ Deacon (1997), p. 345.

${ }^{26}$ Bechtel and Abrahamsen (2005).

27 Bargh (2005), p. 50; see Bruner's introduction to Luria (1961); Donald (2001), p. 250.

${ }^{28}$ Chapter 2 of Thinking and Speech (formerly translated as Thought and Language) is devoted to Piaget, as is chapter 6, in
} part.
Thus the central tendency of the child's development is not a gradual socialization introduced from the outside, but a gradual individualization that emerges on the foundation of the child's internal socialization. ${ }^{29}$

In the Spinozist terms outlined above, we don't compose the network(s), they compose us. So far, this is pretty well known - we've just restated the necessarily social character of mind or intelligence. Granted that the individual is social and cannot be defined without reference to social factors as primary as the relation of child to mother, what is new is something further, and tied to plasticity: there may even be evidence of consequences in our central nervous system derived from early social interaction. Past experience is embodied in synaptic modifications. The functional organization of the human brain can be said, in both the Vygotski-Luria sense and in Deacon's sense, to reflect socially determined forms or types of activity. As Alexandre Métraux puts it, the origins of the higher psychological functions such as thinking, believing, wanting, etc. are not to be sought in the brain or some hidden spiritual entity called 'spirit' or 'mind', but in the activity of the members of a society. ${ }^{30}$ These higher functions, one can add, emerge out of "the dialectical interaction between specific biological structures (embodiment) and culture (situatedness) through a specific history of development (epigenesis). ${ }^{\prime 31}$ More dramatically put, as Luria does:

The fact that in the course of history man has developed new functions does not mean that each one relies on a new group of nerve cells [...]. The development of new 'functional organs' occurs through the development of new functional systems, which is a means for the unlimited development of cerebral activity. The human cerebral cortex, thanks to this principle, becomes an organ of civilization in which are hidden boundless possibilities. ${ }^{32}$

He adds that

Social history ties the knots that produce new correlations between certain zones of the cerebral cortex. $^{33}$

Now we begin to see something new, namely what I referred to as "the socialist cortex": Aaron Zalkind declared (as quoted by Vygotski) that "The cortex is on a shared path with socialism, and socialism is on a shared path with the cortex. ${ }^{34}$ A kind of avant-gardism! And Vygotski himself asserts that

\footnotetext{
${ }^{29}$ Vygotski, Thinking and Speech, ch. 7, in Vygotski (1987), p. 259.

${ }^{30}$ Métraux (ms.), § III.

${ }^{31}$ Zlatev (2001), p. 190.

${ }^{32}$ Luria (1967), in Luria (1978), p. 279. Luria is developing themes from Vygotski's "Psychology and the Theory of the Localization of Mental Functions," translated in Vygotski (1997).

${ }^{33}$ Luria (1967) in Luria (1978), p. 279.

34 Aaron Zalkind (Bolshevik child psychologist), quoted in Vygotski, Pedologija Podrotska, vol. 1 (Moscow, 1929), p. 14; quoted in van der Veer \& Valsiner (1991), p. 320.
} 
History, changing the human type, depends on the cortex; the new socialist man will be created through the cortex; upbringing is in general an influence upon the cortex. 35

If this were a longer study it would useful at this point to look into the question of Vygotski's Marxism. He rejected most of the attempts in his day to link Marxism to psychology - including, as we saw, one by Luria - as being inadequate and misconceived; his claim that human mental functions are irreducibly social does not have to be seen as per se derived from Marxism, although he connects himself to this tradition in many other ways, but from the French sociological tradition of Durkheim, Lévy-Bruhl, and Halbwachs. ${ }^{36}$ However, the claim that mind/brain must be understood as "the aggregate of internalized social functions," once relations have become functions for the individual, ${ }^{37}$ is explicitly derived from Marx's Sixth Thesis on Feuerbach: "Human essence in its reality is the sum of social relations." ${ }^{38}$ Vygotski is seeking to put cerebral 'flesh' onto the ontological 'skeleton' of the Marxian claim that we are defined at our core by the set of social relations to which we belong; he agrees with the broad 'relational' framework but seeks to give it some naturalistic basis in an account of the development of mind.

Notice, however, that Vygotski's 'socialist cortex' stands or falls as a concept without Marxist theory. We would be more likely today to speak of plasticity, of the effect of various ecological dimensions on cerebral development, including the role of maternal care in hippocampal plasticity (in young rats) ${ }^{39}$ and the effects of cortical microstimulation in "quantifying the relation between perception and neuronal activity" and thereby, "inducing a phenomenal state" 40 ; more speculatively, instead of specifically calling the cortex the organ for socialism, we would point, following Terrence Deacon, to the manifestations in cortical architecture of our symbolic, linguistic, and even cultural life. We are a 'symbolic species', in Deacon's phrase, not because symbols float around in our bloodstream, but because "symbols have played a major role in shaping our

\footnotetext{
${ }^{35}$ Vygotski (1929), quoted in van der Veer \& Valsiner (1991), p. 320.

36 In particular Halbwachs' Cadres sociaux de la mémoire (1925), which stressed the 'reconstructive' dimension of memory; see Kozulin (1990), pp. 122-123. For a different view which emphasizes the Marxist dimension more strongly see Wertsch (1985), p. 58f., or Métraux's comment that Vygotski's "consistent Spinozist viewpoint" is also a "consistent Marxist viewpoint" (1992, p. 206). I find the latter reading a bit more convincing (see the image of the cortex and socialism) but it is clear that Vygotski, like Lukács, Althusser or Negri after him, has to invent a heterodox form of Marxism.

37 Vygotski, "The genesis of higher mental functions," in Wertsch, ed. (1981), p. 164.

38 "das menschliches Wesen (...) in seiner Wirklichkeit ist das Ensemble der gesellschaftlichen Verhältnisse."

${ }^{39}$ Champagne, Bagot et al. (2008).

${ }^{40}$ Respectively, Romo, Hernández et al. (1998), pp. 387-388 and Bickle \& Ellis (2005), p. 159.
}

cognitive capacities in ways that are complementary to their special functional demands" "41; "language has given rise to a brain which is strongly biased to employ the one mode of associative learning that is most critical to it," "the most extensive modification to take place in human brain evolution, the expansion of the cerebral cortex, specifically the prefrontal cortex, reflects the evolutionary adaptation to this intensive working memory processing demand imposed by symbol learning." ${ }^{43}$ Hence there is a 'co-evolution' of language and the brain. We have learned since at least Walter Benjamin to recognize the historicity of perception; Luria recognized this through his experiments on visual illusions during trips to Uzbekistan in the 1930s; different subject groups, depending on their degree of Westernization, had a more or less high chance of seeing the illusions: "the more the subjects had dealt with abstract aspects of everyday practice, the less their vision was natural. ${ }^{, 44}$

The idea is that the brain itself, less in its 'static', anatomical being than in its 'dynamic', physiological being - in actu, then - displays features which reflect its embeddedness in or belonging to the social world. The externalist-Spinozist point to be derived from Deacon's coevolution thesis is that we can only have knowledge about the inner states of others, and indeed, of our own, thanks to the overall structure of symbolic activity which (externally) exhibits the existence of such states, and further, creates the structure in which such states emerge.

Most people don't realize that Vygotski and Luria meant the brain itself when speaking about these dynamic, selftransformative features; they usually describe these as belonging to mind or intellect. But Vygotski and Luria were materialists! (In both the Marxist sense that they believed in the primacy of productive activity over theory and intellectual activity in general, and the more naturalistic sense that they believed intellectual processes could be explainable in terms of, or at least in a causally integrated relation to, cerebral processes. ${ }^{45}$ ) The brain for them is no longer just an 'organ' mediating between mind and society, through language - not just a "physiological abstraction," as Feuerbach put it. ${ }^{46}$ Extending from the social mind to the social brain is a major step towards, or for materialism.

${ }^{41}$ Deacon (2003), p. 95.

${ }^{42}$ Deacon (1997), p. 336.

${ }^{43}$ Deacon (2003), p. 100.

${ }^{44}$ Métraux (ms.), § III.

${ }^{45}$ Thanks to an anonymous reviewer for querying this and thus eliciting some clarification. There is no neat formulation which clarifies the relation between brain-mind materialism (and its complexities) and a more socially embedded materialism, in any of the authors discussed here; nor is this relation necessary. Vygotski and Luria, like Deacon (and Baldwin, Dewey and Negri in some of their moods) espouse both.

${ }^{46}$ Feuerbach, "Against the dualism of soul and body." Compare Bergson's (1896) image of the brain as the "bureau téléphonique central," as a mere "intermediary" between sensations and motions" (pp. 26, 198) ... which Vygotski finds too dualistic! (Vygotski [1997], p. 125). 
However, neither neurally correlated social cognition nor even Machiavellian primates seem to display anything like the activity of the 'socialist cortex', our shorthand for the transformative dimension of the plastic, socially plastic brain. For this we need not only Spinozist affects (along with his reduction of the universe to relations between portions of motion and rest), but a theory of transformation. Behind Vygotski and Negri, there is also Marx.

\section{The social brain}

As I mentioned at the outset, the notion of social brain appears in Marx's Grundrisse, notebooks VI-VII. Marx writes about what he calls the "general productive forces of the social brain. ${ }^{, 47} \mathrm{He}$ suggests that, because of increasing use of automation and of developing networks of communication and transportation:

... [T] he production process has ceased to be a labour process in the sense of a process dominated by labour as its governing unity. Labour appears rather as a conscious organ, scattered among the individual living workers at various points of the mechanical system; subsumed under the total process of the machinery itself, as itself only a link of the system, whose unity exists not in the living workers, but rather in the living (active) machinery, which confronts his individual, insignificant doings as a mighty organism. ${ }^{48}$

A few pages later he remarks that

... [N]ature builds no machines, no locomotives, railways, electric telegraphs, self-acting mules etc. These are products of human industry; natural material transformed into organs of the human will over nature, or of human participation in nature. They are organs of the human brain, created by the human hand; the power of knowledge, objectified. The development of fixed capital indicates to what degree social knowledge has become a direct force of production, and to what degree, hence, the conditions of the process of social life itself have come under the control of the general intellect and been transformed in accordance with it. ${ }^{49}$

What Marx is saying is that the real 'operator' or 'agent' of transformation, indeed the sole remaining actor in this process, is the social brain; it has become the productive force itself. "Rather than an allusion to the overcoming of the existent, the 'Fragment' is a sociologist's toolbox and the last chapter of a natural history of society. ${ }^{, 50}$ That is, it is meant as a description of empirical reality. ${ }^{51}$ The actor is neither the machines by themselves nor the old-fashioned humanist 'autonomous rational animal', but rather the 'General Intellect', which resides both in humans and in

\footnotetext{
${ }^{47}$ Marx (1973), p. 694.

${ }^{48}$ Ibid., p. 693.

${ }^{49}$ Ibid., p. 706, emphasis his own.

50 Virno (2001b), section on "Marx, Simondon, Vygotski"; Marx (1973), p. 709.

${ }^{51}$ Virno (2001a), (2007).
}

intelligent machines. Comparisons have been made ${ }^{52}$ between this idea of 'General Intellect' and Teilhard de Chardin's 'noosphere', and indeed there is something uncomfortably spiritualistic about the idea, as if intellect were more real than a piece of flesh or silicone. This may indeed be a Hegelian residue in Marx, a residue of 'Geist'. If I am emphasizing the term 'social brain' here, it's precisely to show that it's part of the real ('wet' rather than 'dry') natural world. Further, just because the brain is irreducibly social does not mean that it is an 'empire within an empire' or 'kingdom within a kingdom' (in Spinoza's famous phrase from the Preface to Book III of the Ethics: imperium in imperio). I refer back to the Spinozist ontology of relations and find support in this also from Negri's recurring invocations of 'ontology' as a political necessity. ${ }^{53}$

The Spinozist brain, the social brain cannot be extracted or abstracted from this universe of relations (recall Vygotski's arguments against Piaget's 'egocentric' perspective). As such, it cannot or should not be confused

- with the phenomenological outlook ('Man thinks, not the brain'), or with Varela's enactivist model, which is rich and full of possibilities but hardly socio-political ones; Varela is our Piaget, in a sense: a new idealist, a new metaphysically grounded solipsist for whom the Self is selfpositing, self-grounding rather than constituted in and through relation, or challenges of the 'outside', whether this is construed as a Darwinian environment or a Spinozist causal universe. ${ }^{54}$

- with, at the other extreme, 'good old-fashioned computational Artificial Intelligence' (although Gallese's work hints at a new, socially oriented understanding of the single neuron doctrine), because the social brain is both material (wetware rather than dryware) and other-directed;

- with, lastly, the traditional distinction between natural sciences and human sciences, which its very name seeks to overcome. No distinction here between the brute, inanimate world of nature, animals and machines on the one hand and a free, spiritual world of self-interpreting Daseine on the other hand. Suffice it to recall here the charming formula Negri (1995) proposed for understanding Deleuze-Guattari's Mille plateaux: that it was the last great work of the Geisteswissenschaften, but where Geist was replaced by the brain.

In a sense, the novelty of the concept of social brain appears most striking in regard to the last item (which it is not), the hermeneutical self. If we recall that Vygotski's concepts are born out of a reflection on linguistic development, and that the 'affective' dimension that both Vygotski, Negri and Virno draw out of Spinoza is 'always already' social - such that the general intellect itself is

\footnotetext{
${ }^{52}$ Gere (2004).

${ }^{53}$ On the meaning of 'ontology' in Negri see Wolfe (2007a).

${ }^{54}$ Hence it is understandable that Luria was critical of Kurt Goldstein, another (brilliant) forerunner of Varela's. See e.g. Luria (1967) in Luria (1978), p. 277. I elaborate this point with reference to the concept of organism in Wolfe (forthcoming).
} 
permeated with the "linguistic cooperation of a multitude of living subjects" 55 - we can see a bit better why the distinction between the natural and the 'hermeneutical' is of little use here. The potential of an agent is inseparable from what Negri calls the 'set of prostheses', 56 essentially the possible set of scaffolding, networks and technological extensions of our perception, cognition and action. ${ }^{57}$

The tool $[\ldots]$ has entirely changed. We no longer need tools in order to transform nature $[\ldots]$ or to establish a relation with the historical world [...], we only need language. Language is the tool. Better yet, the brain is the tool, inasmuch as it is common. ${ }^{58}$

One can see resonances here with the work both of Donna Haraway (with the focus on the category of prosthesis and the primacy of artificiality) and, surprisingly perhaps, of Richard Dawkins (specifically, the notion of 'extended phenotype', according to which the genes of an organism can be expressed beyond its immediate biological boundary - beavers' dams, birds' nests, but also the behavior of hosts infected by parasites; here, the border of the gene is no longer the skin). ${ }^{59}$

The brain is "common" inasmuch as it is constituted by and inseparable from the network of relations to which we belong. What Spinoza's common notions, Marx's General Intellect and the Vygotskian 'socialist cortex' indicate is precisely this commonness, as opposed to the 'classic' idea of thinking as a solitary, contemplative activity. Given this commonness, there is no longer a separation between brain and tool as two distinct entities. ${ }^{60}$ Indeed, in his day Vygotski was attacked by Party psychologists for 'virtualizing' the concept of tool or that of labor, and allowing for 'mental' factors such as culture to be determinations, rather than strict economic factors. ${ }^{61}$

What this implies for current discussions of group cognition can only be hinted at briefly. ${ }^{62}$ First, there is no absolute ontological separation between an individual agent and her brain, and the total network of affects, objects and structures around her. Second, individuation is an effect of power, both in the Vygotskian sense that 'I' am a product of socialization, and not the other way round, and in the

\footnotetext{
${ }^{55}$ Virno (2004).

${ }^{56}$ Negri (2000), $\S 16$ b. These texts are also republished in Negri (2005).

${ }^{57}$ See the discussion of plasticity-remapping-'cultured brain' in Neidich (2003) for more on this aspect, and Wolfe (2007b); Neidich's idea has its own potential for being restated as a new form of what phenomenologists call 'self-affection', just as Marxist-operaist General Intellect has a potential to be restated as Pure Mind: ultimate idealism.

${ }^{58}$ Negri (2000), § 16 b.

${ }^{59}$ I thank Luc Faucher for the latter suggestion.

${ }^{60}$ Negri (2001), § 16bis, p. 84.

${ }^{61}$ A.A. Talankin, speaking at the First All-Union Congress on Psychotechnics and the Psychophysiology of Labor, Leningrad, 1931. He also attacks Vygotski on the related charge of importing 'Western' concepts from Freud and Gestalt theory into Soviet psychology. See van der Veer \& Valsiner (1991), p. 377.

${ }^{62}$ Thanks to Georg Theile for querying this.
}

Spinozist sense that the more 'extensions' I have - a notebook, a computer, a pen, a knot in my handkerchief, a friend's telephone number, a Party membership card, and so forth - the greater my power of acting will be. Not just in a trivial sense of 'greater influence', but because (recall the idea of common notions) I will have more ideas of more bodies. Third, the social brain concept presented is definitely not reducible to the individual's manifestations of a social world around her, since on the contrary (pace Vygotski, Deacon and others) cerebral architecture reflects, however minutely, forms of social, linguistic, cultural organization. Does the group then have a 'group mind'? The foregoing discussion does not necessarily entail that. I have simply tried to show that there is a way of thinking about the brain which retains a socio-political dimension while at the same time dealing with naturalistically specifiable features of development; a genuinely materialist perspective.

From the social dimension of mind - materialized through ethological and single-neuron studies, ontologically founded with the doctrine of common notions and of being as relation - through the fundamental plasticity of the brain and the remodelling by language and culture of the functional architecture of the cortex: this is the Spinozist tradition of the social brain.

\section{Acknowledgments}

Versions of this paper have been presented at Goldsmiths College (London), the Université de Grenoble and Macquarie University. Thanks to Luc Faucher, Tom Froese, Georg Theiner and an anonymous reviewer for helpful feedback or suggestions.

\section{References}

Alač, M. (2008). Working with Brain Scans: Digital Images and Gestural Interaction in fMRI Laboratory. Social Studies of Science 38, 483-508

(Anon.) (2001). L'hypothèse cybernétique. Tiqqun 2.

Baldwin, J.M. (1896). A new factor in evolution. American Naturalist 30:354, 441-451. Online at http://www.brocku.ca/MeadProject/Baldwin/Baldwin_18 96 h.html

Bargh, J.A. (2005). Bypassing the will: Toward demystifying the nonconscious control of social behavior. In R. Hassin, J. S. Uleman \& J.A. Bargh (Eds.), The New Unconscious (pp. 37-58). New York: Oxford University Press

Bechtel, W. \& Abrahamsen, A. (2005). L'explication mécaniste et la controverse de l'inné et de l'acquis. Bulletin d'Histoire et d'Epistémologie des Sciences de la Vie 12:1, 75-100; original English ms. available at URL :

http://mechanism.ucsd.edu/ bill/research/MechanisticExpla nationandtheNatureNurtureControversy.pdf

Bergson, H. (1896). Matière et mémoire. Paris: PUF. 
Bickle, J. \& Ellis, R. (2005). Phenomenology and Cortical Microstimulation. In D. Woodruff Smith \& A. Thomasson (Eds.), Phenomenology and the Philosophy of Mind (pp. 140-163). Oxford: Oxford University Press.

Blakemore, S. Winston, J. \& Frith, U. (2004). Social cognitive neuroscience: where are we heading?, Trends in Cognitive Sciences 8:5, 216 - 222

Brothers L. (1990). The social brain: a project for integrating primate behaviour and neuropsychology in a new domain. Concepts in Neuroscience 1, 27-51.

Byrne, R. \& Whiten, A. (Eds.) (1989). Machiavellian Intelligence: Social expertise and the evolution of intellect in monkeys, apes and humans. Oxford: Clarendon Press.

Cacioppo, J.T., \& Berntson, G.G. (2004a). Analyses of the social brain through the lens of human brain imaging. In J.T. Cacioppo \& G.G. Berntson (Eds.), Key readings in social neuroscience (pp. 1-17). New York: Psychology Press.

(2004b). Essays in social neuroscience.

Cambridge, MA: MIT Press

Champagne, D.L., Bagot, R.C., van Hasselt, F., Ramakers, G., Meaney, M.J., de Kloet, E.R., et al. (2008). Maternal care and hippocampal plasticity: Evidence for experiencedependent structural plasticity, altered synaptic functioning, and differential responsiveness to glucocorticoids and stress. Journal of Neuroscience 28, 6037-6045.

Clark, A. (1997). Being There. Putting Brain, Body and World Back Together Again. Cambridge, MA: MIT Press. (2002). Natural-Born Cyborgs. Minds, Technologies and the Future of Human Intelligence. Oxford: Oxford University Press. and Chalmers, D.J. (1988). The Extended Mind. Analysis 58, 10-23. URL: http://consc.net/papers/extended.html

Damasio, A. (2003). Looking for Spinoza: Joy, Sorrow, and the Feeling Brain. New York: Harcourt.

Deacon, T. (1997). The Symbolic Species. New York: W.W. Norton.

(2003). Multilevel selection in a complex adaptive system: the problem of language origins. In D. Depew \& B. Weber (Eds.), Evolution and Learning. The Baldwin Effect Reconsidered (pp. 81-106). Cambridge MA: MIT Press.

Depew D. \& Weber, B.H. (Eds.) (2003). Evolution and Learning: The Baldwin Effect Reconsidered. Cambridge MA: MIT Press.

Donald, M. (2001). A mind so rare. New York: Norton.

Dunbar, R. (1998). The social brain hypothesis. Evolutionary Anthropology 6, 178-190.

et al. (Eds.) (2009). Social Brain, Distributed

Mind. Oxford: Oxford University Press.

Gallese, V. (2000). The acting subject: towards the neural basis of social cognition. In T. Metzinger, ed., Neural Correlates of Consciousness. Empirical and Conceptual Questions (pp. 325-333). Cambridge, MA: MIT Press.
\& Goldman, A. (1998). Mirror neurons and the simulation theory of mind-reading. Trends in Cognitive Sciences 2:12, 493-501

\& Keysers, C. \& Rizzolatti, G. (2004). A unifying view of the basis of social cognition. Trends in Cognitive Sciences 8:9, 396-403

Gere, C. (2004). Brains-in-vats, giant brains and world brains: the brain as metaphor in digital culture. Studies in History and Philosophy of Biological and Biomedical Sciences 35:2, 351-366

Gibson, J.J. (1979). The Ecological Approach to Visual Perception. Boston: Houghton Mifflin.

Goldman, A. (2005). What Is Social Epistemology? A Smorgasbord of Projects (ms.) - in translation in E. Pacherie \& J. Proust (Eds.), Philosophie cognitive, Paris: Editions de la Maison des sciences de l'homme / CNRS.

d'Holbach, P.-H.T., Baron (1781/1990). Système de la Nature ou des lois du monde physique et du monde moral, 2 vols., reprint of $2^{\text {nd }}$ edition, ed. J. Boulad-Ayoub. Paris: Fayard, coll. Corpus

Hurley, S. \& Chater, N. (Eds.) (2005). On Imitation: From Neuroscience To Social Science, 2 vols. Cambridge, MA: MIT Press.

Hutchins, E. (1995). Cognition in the Wild. Cambridge, Mass.: MIT Press.

Keysers, C. \& Perrett, D. (2004). Demystifying social cognition: a Hebbian perspective. Trends in Cognitive Sciences 8:11, 501-507

Kozulin, A. (1990). Vygotsky's Psychology. Cambridge, MA: Harvard University Press.

Losonsky, M. (2001). Enlightenment and Action. Cambridge: Cambridge University Press.

Lotringer, S. \& Marazzi, C. (Eds.) (1980/2007). Autonomia: Post-Political Politics. New York: Semiotext(e).

Luria, A.R. (1961). The role of speech in the regulation of normal and abnormal behavior. New York: Liveright / Oxford: Pergamon Press.

(1967). L.S. Vygotski and the Problem of Functional Localization. Soviet Psychology 5:3, 53-57, reprinted in Luria (1978)

(1978). The Selected Writings of A.R. Luria, ed. M. Cole. New York: M.E. Sharpe.

Marx, K. (1973). Grundrisse: Foundations of the Critique of Political Economy. Harmondsworth: Penguin.

Métraux, A. (1992). Die zerbrochene Psychophysik. Anmerkungen zu Lev Vygotskijs Spinoza-Rezeption. Studia Spinozana 8, 191- 208

on the mind/body problem and Luria's neuropsychology (ms.)

Metzinger, T. \& Gallese, V. (2003). The emergence of a shared action ontology. Building blocks for a theory. Consciousness and Cognition 12:4, 549-571

Morfino, V. (2003). Ontologie de la relation et matérialisme de la contingence. Actuel Marx 18, n.p.

(2006). Revised and shortened version of (2003). published as Spinoza: An Ontology of Relation? 
in Graduate Faculty Philosophy Journal, New School for Social Research, 27:1, 103-127

Negri, A. (1984). Marx Beyond Marx, trans. H. Cleaver, M. Ryan \& M. Viano, ed. J. Fleming. New York: Autonomedia.

(1989). The Politics of Subversion, trans. J. Newell. Oxford: Polity / Blackwell.

(1995). On A Thousand Plateaus. Trans. C.T. Wolfe. Graduate Faculty Philosophy Journal 18:1, 93109 , online

at http://www.korotonomedya.net/theoria/Negri 1000platea us.html

(2000). Alma Venus. Prolegomena to the Common. Trans. P. Dailey \& C. Costantini. In C.T. Wolfe, ed., The Renewal of Materialism (Graduate Faculty Philosophy Journal 22:1, New York, New School for Social Research)

(2001). Kairos. Alma Venus. Multitude, trans.

J. Revel. Paris: Calmann-Lévy.

(2005). Time for Revolution, trans. Matteo Mandarini. London: Continuum.

Neidich, W. (2003). Blow-Up. Photography, cinema and the brain. New York: Distributed Art Publishers.

Romo, R., Hernández, A. et al. (1998). Somatosensory Discrimination Based on Cortical Microstimulation. Nature 392: 6674, 387-390.

Spinoza, B. (1676/1992). Ethics, in Ethics / Treatise on the Emendation of the Intellect / Selected Letters, trans. Samuel Shirley. Indianapolis: Hackett.

van der Veer, R. (1997). Some Major Themes in Vygotski's

Work. In Vygotski, Collected Works, vol. 3

van der Veer, R. \& Valsiner, J. (1991). Understanding Vygotsky. A Quest for Synthesis. London: Blackwell.

Virno, P. (2001a). General Intellect. Lessico Postfordista. Milan: Feltrinelli.

(2001b). Multitude et principe d'individuation. Multitudes 7, 103-117 — also at the URL http://multitudes.samizdat.net/article.php3?id_article $=65$

(2004). Les anges et le general intellect. L'individuation chez Duns Scot et Gilbert Simondon. Multitudes 18, also at the URL http://multitudes.samizdat.net/Les-anges-et-le-general$\underline{\text { intellect }}$

(2007), "General Intellect," translation of Virno (2001a) by A. Bove in Historical Materialism. Research in Critical Marxist Theory 15:3, 3-8.

Vygotski, L.S. (1972). Spinoza's Theory of the Emotions in Light of Contemporary Psychoneurology. Trans. E. Berg. In Soviet Studies In Philosophy 10, 362-382

(1978). Mind in Society, ed. \& trans. M. Cole et al. Cambridge, MA: Harvard University Press.

(1987). The Collected Works of L.S. Vygotsky, vol. 1: Problems of General Psychology, ed. R.S. Rieber \& A.S. Carton, trans. N. Minick. New York: Plenum Press.

(1997). The Collected Works of L.S. Vygotsky, vol. 3: Problems of Theory and Method in Psychology, ed.
R.S. Rieber \& J. Wollock, trans R. van der Veer. New York: Plenum Press.

Online archive of Vygotski's writings: http://www.marxists.org/archive/vygotsky/

Wertsch, J.V. (1985). Vygotski and the Social Formation of Mind. Cambridge, MA: Harvard University Press.

(Ed.) (1981). The Concept of Activity in Soviet Psychology. New York: M.E. Sharpe.

Whiten, A. \& Byrne, R.W. (Eds.) (1997). Machiavellian Intelligence II : Extensions and Evaluations. Cambridge: Cambridge University Press.

Wolfe, C.T. (2007a). Materialism and Temporality. Antonio Negri's 'Constitutive' Ontology. In T.S. Murphy \& A.-K. Mustapha (Eds.), The Philosophy of Antonio Negri 2: Revolution in Theory (pp. 196-218). London: Pluto Press. (2007b). De-ontologizing the Brain: from the fictional self to the social brain. CTheory 30:1 (Winter): http://www.ctheory.net/articles.aspx?id=572

(forthcoming 2010). Do organisms have an ontological status? On the dangers of crying 'reductionist!' In P. Huneman and C.T. Wolfe (Eds.), The Concept of Organism. Historical, Philosophical, Scientific Perspectives. Special issue of History and Philosophy of the Life Sciences.

Zlatev, J. (2001). The Epigenesis of Meaning in Human Beings, and Possibly in Robots. Minds and Machines 11, $155-195$

\section{Citation details for this article:}

Wolfe, C. (2010). The Social Brain: a Spinozist Reconstruction. In W. Christensen, E. Schier, and J. Sutton (Eds.), ASCS09: Proceedings of the 9th Conference of the Australasian Society for Cognitive Science (pp. 366-374). Sydney: Macquarie Centre for Cognitive Science.

DOI: $10.5096 / A S C S 200956$

URL:

http://www.maccs.mq.edu.au/news/conferences/2009/ASCS 2009/html/wolfe.html 